\title{
Water potential and gas exchanges in sugarcane irrigated with saline waters
}

\author{
Raquele M. de Lira ${ }^{1}$, Ênio F. de F. e Silva², Marcone da S. Barros ${ }^{3}$, \\ Leandro C. Gordin ${ }^{2}$, Lilia G. Willadino ${ }^{2}$ \& Rodrigo F. Barbosa ${ }^{2}$
}

${ }^{1}$ Universidade Federal Rural de Pernambuco/Unidade Acadêmica de Serra Talhada/Departamento de Agronomia. Serra Talhada, PE. E-mail: raquelelira@gmail.com (Corresponding author) - ORCID: 0000-0002-9035-7788

${ }^{2}$ Universidade Federal Rural de Pernambuco/Departamento de Engenharia Agrícola/Programa de Pós Graduação em Engenharia Agrícola. Recife, PE. E-mail: enio.fsilva@ufrpe.br - ORCID: 0000-0002-8652-503X; leandrocandidog@hotmail.com - ORCID: 0000-0002-6452-6007; willadino.lilia@gmail.com - ORCID: 0000-0003-0491-4443; sdfbarbosa@gmail.com - ORCID: 0000-0003-2932-3092

${ }^{3}$ Universidade Federal Rural de Pernambuco/Departamento de Agronomia. Recife, PE. E-mail: marconebarroos@gmail.com - ORCID: 0000-0003-0948-573X

\section{Key words:}

Saccharum spp.

salinity

irrigation

\begin{abstract}
A B S T R A C T
In Pernambuco, state in the northeastern region of Brazil, in the coastal areas, due to the intrusion of seawater, the waters used for sugarcane irrigation can have high salt contents and cause serious problems to soil and plant. The present study aimed to evaluate the effects of irrigation with saline water on the physiology of sugarcane, variety RB867515, irrigated under five salinity levels of $0.5 ; 2.0 ; 3.5 ; 5.0$ and $6.5 \mathrm{dS} \mathrm{m}^{-1}$ in a completely randomized design, with four replicates in drainage lysimeters. The study was conducted in the period from December 2014 to June 2015, at the Federal Rural University of Pernambuco (UFRPE). Salinity levels were obtained by dissolving $\mathrm{NaCl}$ and $\mathrm{CaCl}_{2}$ in water from the local supply system $\left(\mathrm{ECw}=0.5 \mathrm{dS} \mathrm{m}^{-1}\right)$. Leaves were analyzed for stomatal conductance, transpiration and photosynthesis at 140, 229 and 320 days after planting (DAP) and for water potential at 137, 243 and 318 DAP. Increase in irrigation water salinity inhibited all variables at the respective plant ages and with greater intensity in the first evaluations (140 and 229 DAP) for stomatal conductance and transpiration. Photosynthesis and water potential showed the greatest linear reductions at the last data collection (320 and 318 DAP), respectively. Increase in salinity of irrigation water hampered water potential and gas exchange in the leaves of RB867515 sugarcane.
\end{abstract}

\section{Palavras-chave:}

Saccharum spp.

salinidade

irrigação

\section{Potencial hídrico e trocas gasosas em cana-de-açúcar irrigada com águas salinas}

\section{R E S U M O}

Em Pernambuco, estado da região nordeste do Brasil, nas áreas litorâneas, devido à intrusão da água do mar, as águas utilizadas para irrigação da cana-de-açúcar podem apresentar altos teores de sais e causar sérios problemas no solo e na planta. Com o presente trabalho objetivou-se avaliar os efeitos da salinidade da água de irrigação sobre a fisiologia da canade-açúcar, variedade RB867515, irrigada sob cinco níveis de salinidade de 0,$5 ; 2,0 ; 3,5 ; 5,0$ e $6,5 \mathrm{dS} \mathrm{m}^{-1}$ com delineamento inteiramente casualizado com quatro repetições em lisímetros de drenagem. A pesquisa foi conduzida no período de dezembro de 2014 a junho de 2015, na Universidade Federal Rural de Pernambuco (UFRPE). Os níveis de salinidade foram obtidos pela diluição de $\mathrm{NaCl}$ e $\mathrm{CaCl}_{2}$ à água de abastecimento local $\left(\mathrm{CEw}=0,5 \mathrm{dS} \mathrm{m}^{-1}\right)$. Nas folhas foram feitas leituras de condutância estomática, transpiração e fotossíntese aos 140, 229 e 320 dias após o plantio (DAP) e do potencial hídrico aos 137, 243 e 318 DAP. $\mathrm{O}$ aumento da salinidade da água de irrigação inibiu todas as variáveis nas respectivas idades das plantas e com maior intensidade nas primeiras avaliações (140 e 229 DAP) para condutância estomática e transpiração. A fotossíntese e o potencial hídrico apresentaram maiores reduções lineares na última coleta de dados (320 e 318 DAP) respectivamente. $\mathrm{O}$ aumento da salinidade da água de irrigação prejudicou o potencial hídrico e as trocas gasosas nas folhas de cana-de-açúcar RB867515. 


\section{INTRODUCTION}

Brazil is the largest global producer of sugarcane (CONAB, 2017) and in Pernambuco most of the production occurs in the coastal areas. In these areas, due to seawater intrusion, irrigation waters may have high salinity level and cause serious problems of production. In these situations, the effects of salts on plants cause restrictions in $\mathrm{CO}_{2}$ assimilation, decline in chlorophyll content, leading to losses in photosynthesis, among other metabolic alterations (Munns \& Tester, 2008; Chaves et al., 2009).

High concentration of salts in the soil reduces the osmotic potential, compromising water absorption by plants, especially in sensitive species. Sugarcane is a glycophyte moderately sensitive to salts (Sengar et al., 2013; Kumar et al., 2014) and, when subjected to salinity, its evapotranspiration is reduced, especially in the initial stages of cultivation (Santana et al., 2007).

Water stress, which can be originated from the effect of salinity (Mortele et al., 2006), has effect on canopy architecture, playing an important role in the yield, because the canopy intercepts light, affecting the processes of photosynthesis and transpiration (Smit \& Singels, 2006; Trentin et al., 2011).

Water potential in the leaf is very important to understand the water relations in the plant and between plant and external environment (soil and atmosphere) (Correia, 2014). This potential provides a relative index of the water stress to which the plant is subjected, identifying various physiological alterations, in which the most affected process is cell growth, followed by photosynthesis (Taiz et al., 2017).

Salinity hampers gas exchanges in glycophyte plants in general, including the physiology of sugarcane (Souto Filho et al., 2014; Andrade et al., 2015). In this context, this study aimed to evaluate the effects of irrigation water salinity on the responses of gas exchange and water potential in irrigated sugarcane, variety RB867515, using water with increasing salinity levels.

\section{Material AND Methods}

The study was carried out at the Irrigated Agricultural Station Prof. Ronaldo Freire de Moura, located in the Department of Agricultural Engineering (DEAGRI) of the Federal Rural University of Pernambuco (UFRPE), Campus of Recife, at $8^{\circ} 1^{\prime} 5^{\prime \prime} \mathrm{S}, 34^{\circ} 56^{\prime} 48^{\prime \prime} \mathrm{W}$ and altitude of $6.5 \mathrm{~m}$, according to the SAD 69 (South American Datum) system.

The lysimeters used had capacity for $1000 \mathrm{~L}$ each, external diameter of $1.38 \mathrm{~m}$ and height of $0.745 \mathrm{~m}$, buried at $0.65 \mathrm{~m}$ depth, with an edge of $0.10 \mathrm{~m}$ above soil surface to avoid the entry of rainwater or irrigation water, from runoff. These lysimeters were equidistantly placed at $1.20 \mathrm{~m}$ in both directions and the internal drainage system was composed of 50-mm-diameter corrugated pipe, covered with a geotextile to prevent soil particles from entering the drain. A $0.2 \mathrm{~m}^{3}$-layer of crushed stone was placed above the drain and a geotextile was laid above the crushed stone also to serve as a filter. Above the geotextile, each lysimeter received $1070 \mathrm{~kg}$ of dry soil.

The experimental design was completely randomized with 4 replicates, totaling 20 experimental plots. The studied salinity levels were: $\mathrm{T} 1=0.5 ; \mathrm{T} 2=2.0 ; \mathrm{T} 3=3.5 ; \mathrm{T} 4=5.0$ and $\mathrm{T} 5=6.5 \mathrm{dS} \mathrm{m}^{-1}$, obtained by the addition of $\mathrm{NaCl}$ and $\mathrm{CaCl}_{2}$ at molar ratio of $1: 1$ (Ca:Na), respectively, in the water from the local supply system of the UFRPE $\left(\mathrm{ECW}=0.5 \mathrm{dS} \mathrm{m}^{-1}\right)$, using the quantities necessary to achieve the $\mathrm{ECw}$ levels of the respective treatments, according to Rhoades et al. (2000) Eq. 1:

$$
\mathrm{Q}=640 \mathrm{ECw}
$$

where:

Q - quantity of salts $\left(\mathrm{mg} \mathrm{L}^{-1}\right)$; and,

$\mathrm{ECw}$ - desired value of water electrical conductivity $\left(\mathrm{dS} \mathrm{m}^{-1}\right)$.

For the control (T1), only water from the local supply system was used, with no addition of salts. The sugarcane variety RB867515 was used and its cuttings came from the Sugarcane Experimental Station of Carpina (EECACUFRPE); each lysimeter was planted with six cuttings, with two buds each.

In the initial stage of the experiment, irrigations were performed using water from the local supply system, applying $4 \mathrm{~mm}$ every two days in all lysimeters, to ensure sprouting and establishment of the plants. At 60 days after planting (DAP), daily irrigations began using the respective saline waters based on crop evapotranspiration (ETc), calculated as the product between reference evapotranspiration (ETo) and crop coefficient $(\mathrm{kc})$. ETo was obtained according to the climate data of an automatic meteorological station (Campbell Scientific, CR1000/CFM100/OS100) located in the area, which provided the result using the Penman-Monteith equation (Allen et al., 1998). The kc used corresponded to the phenological stage of the plant, according to the Food and Agriculture Organization of the United Nations - FAO (Allen et al., 1998).

A drip irrigation system was used, with four pressurecompensating emitters per lysimeter, spaced at $0.30 \mathrm{~m}$, with mean flow rate measured in the field of $4.2 \mathrm{~L} \mathrm{~h}^{-1}$ per emitter. Irrigation was not applied on days in which rainfall was equal to or higher than crop evapotranspiration.

At 137, 243 and 318 DAP, leaf water potential was analyzed using the Scholander Chamber. Analyses were conducted in the early morning before the sunrise, when the plant is in equilibrium with the surrounding environment.

At 140, 229 and 320 DAP, gas exchange was evaluated: stomatal conductance, photosynthesis and transpiration, using an infrared gas analyzer (IRGA LI-6200). Readings were taken between 11 and $13 \mathrm{~h}$, a time of intense sunshine and high evapotranspiration demand, on a typical day without nebulosity, to avoid instabilities caused by rapid variations in solar radiation.

All analyses were carried out in one leaf per lysimeter, physiologically active and not shaded, in the +3 leaf, according to the numbering proposed by Kuijper (Dillewijn, 1952).

The data were subjected to analysis of variance by $\mathrm{F}$ test $(\mathrm{p}<0.05$ and $<0.01)$ and regression, using the statistical program SISVAR (Ferreira, 2014), and one analysis was performed for each DAP. 


\section{Results AND Discussion}

The increment in water salinity linearly inhibited stomatal conductance at rates of $0.0222,0.0155$ and $0.0143\left(\mathrm{~mol} \mathrm{~m}^{-2} \mathrm{~S}^{-1}\right)$ per unit increase in irrigation water electrical conductivity, regardless of the ages evaluated, but always with greater intensity along plant ages, following the order: $140>229>$ 320 DAP (Figure 1).

Osmotic stress reduces water availability to plants and, consequently, can inhibit gas exchanges and growth (Munns \& Tester, 2008).

Comparatively, stomatal conductance was higher in plants irrigated with water from the local supply system $\left(0.5 \mathrm{dS} \mathrm{m}^{-1}\right)$ than in plants irrigated with more saline waters (Figure 1), at all times evaluated.

At the three times evaluated (140, 229 and 320 DAP), the increase in the concentration of the saline waters led to greater reduction in stomatal conductance, due to the attempt of the plants to adapt to the stress condition. According to InmanBamber et al. (2005), reduction in stomatal conductance is an important strategy of sugarcane to avoid leaf dehydration.

The trend in transpiration data was similar to that of stomatal conductance, i.e., a reduction with the increment in salinity and plant age (Figure 2). Similar situation was reported by Souto Filho et al. (2014), who observed decrease in stomatal conductance and transpiration in two sugarcane varieties, SP813250 and RB92579, subjected to saline stress.

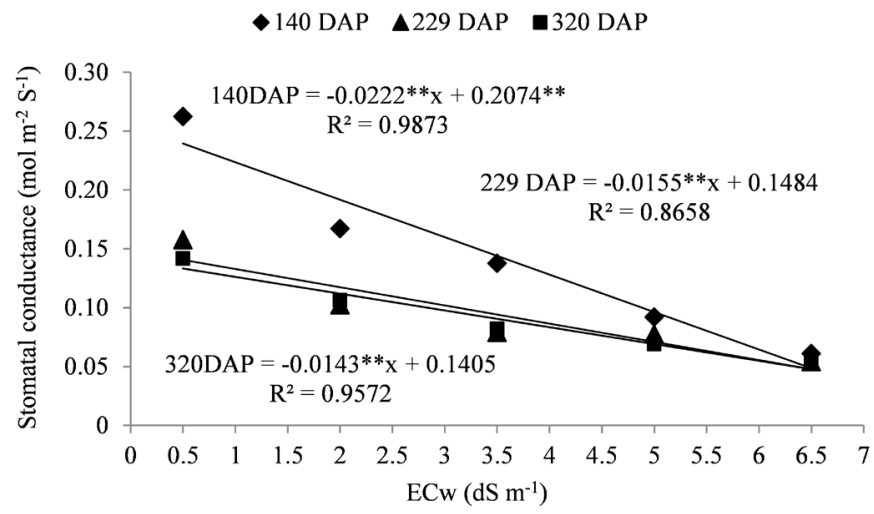

Figure 1. Stomatal conductance in sugarcane, RB867515 variety, subjected to different salinity levels at 140, 229 and 320 days after planting

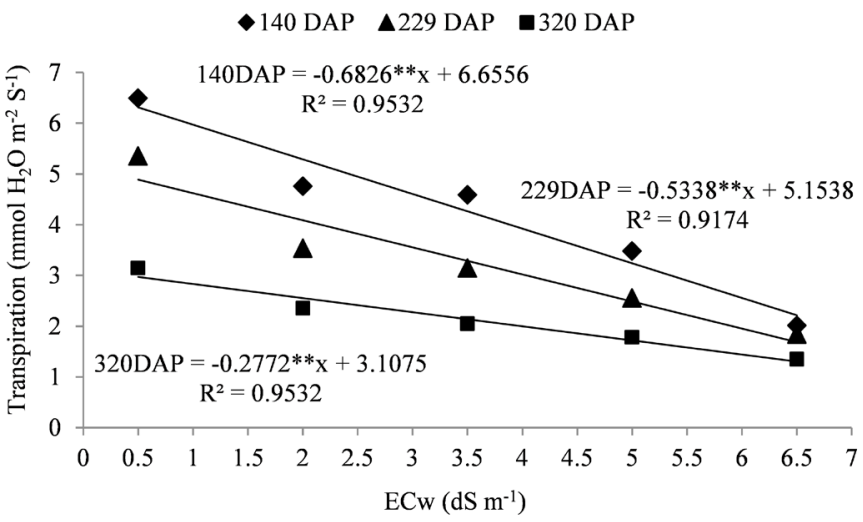

Figure 2. Transpiration rate in sugarcane subjected to different salinity levels at 140, 229 and 320 days after planting
These results also agree with those found by Gonçalves et al. (2010) in sugarcane varieties (SP791011, RB72454, RB98710 and RB92579) subjected to irrigation with saline waters.

Based on the responses of plants over time, at the last evaluation, close to harvest, there were the lowest transpiration and photosynthetic rates, which reflect the reduction in the physiological activity of the plant at the end of its phenological cycle.

Photosynthetic rate (A), as well as gas exchange variables, decreased with the increment in salinity. At 140 DAP, plants that did not receive saline water showed a photosynthetic rate of $17.8 \mu \mathrm{mol} \mathrm{CO} \mathrm{m}^{-2} \mathrm{~m}^{-1}$, whereas in those subjected to the highest saline stress $\left(6.5 \mathrm{dS} \mathrm{m}^{-1}\right)$ the photosynthetic rate was reduced to $6.01 \mu \mathrm{mol} \mathrm{CO} \mathrm{m}^{-2} \mathrm{~m}^{-1}$. Similar values, $5.83 \mu \mathrm{mol} \mathrm{CO} \mathrm{m}^{-2} \mathrm{~m}^{-1}$, were obtained by Souto Filho et al. (2014) at 180 DAP in the sugarcane variety SP813250 subjected to $6.5 \mathrm{dS} \mathrm{m}^{-1}$.

The data found at 229 DAP were close to those of the first analysis at $140 \mathrm{DAP}$, whereas at $320 \mathrm{DAP}$ there was a greater reduction in the photosynthetic rate (Figure 3 ).

Reductions of approximately 11, 13 and $16 \%$ in the photosynthetic rate were observed at 140, 229 and 320 DAP, respectively, per unit increase in water salinity. Andrade et al. (2015) observed reductions of $9.28 \%$ at 139 days after sprouting of sugarcane irrigated with $4.6 \mathrm{dS} \mathrm{m}^{-1}$ water in comparison to those under $0.9 \mathrm{dS} \mathrm{m}^{-1}$ water.

The reductions in gas exchange variables were directly proportional to the time of cultivation. Since no leaching fractions were applied over time, probably there was an accumulation of salts in the soil, which led to reduction in water availability to plants, justifying the decline in gas exchanges.

At 229 DAP, the RB867515 variety, which is known as tolerant to water stress (Silva et al., 2015), exhibited a mechanism of adaptation to saline stress, evidenced at 229 DAP, because even with reduced stomatal conductance (Figure 1), it was able to maintain photosynthetic rates similar to those of plants with 140 DAP (Figure 3), the moment in which stomatal conductance was higher. Studies conducted by Reis \& Campostrini (2008) demonstrate that the photosynthetic rate can be related to stomatal movement.

As observed for the other variables, the increase in the salt content of the waters linearly reduced leaf water potential (Figure 4). There were reductions of $24.50,27.79$, and $66.28 \%$

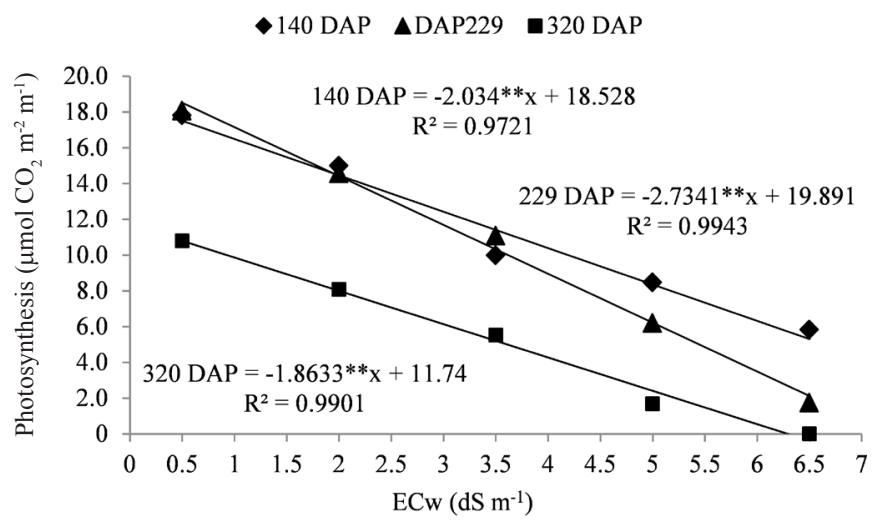

Figure 3. Photosynthetic rate of sugarcane subjected to different salinity levels at 140, 229 and 320 days after planting 


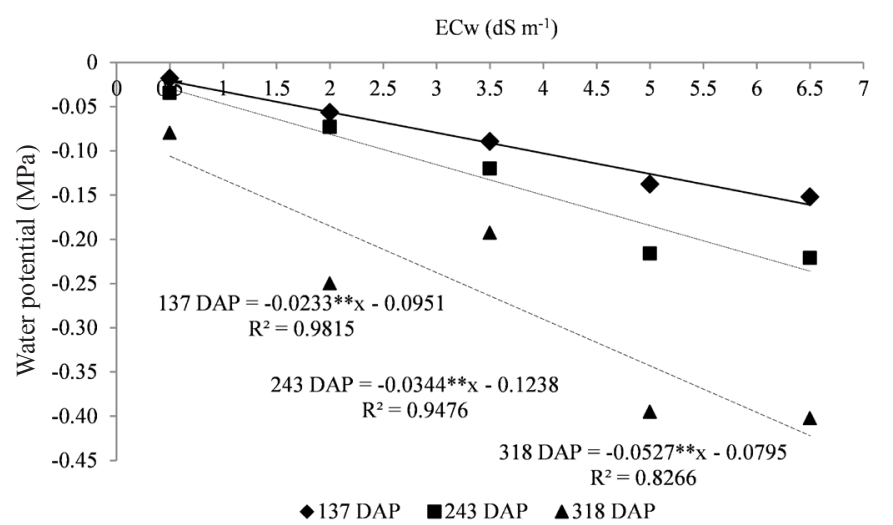

Figure 4. Water potential of sugarcane subjected to different levels of irrigation water salinity at 137 (A), 243 (B) and 318 (C) days after planting

at 137,243 and 318 DAP, respectively, as a function of the increase in water salinity, in $\mathrm{dS} \mathrm{m}^{-1}$. The percent reductions were calculated as the ratio between the angular and linear coefficients $(\mathrm{a} / \mathrm{b})$.

The reduction in water potential probably occurred because of the decline in soil water potential, both osmotic and matric, which leads to limitation in water availability to the plant. As soil water potential decreases, plants need to reduce even more their water potential for water absorption to occur, a process which frequently requires energy expenditure (Muns \& Tester, 2008).

\section{Conclusion}

Increment in irrigation water salinity inhibited water potential, stomatal conductance, transpiration and photosynthetic capacity in the leaves of the sugarcane variety RB867515, regardless of the days evaluated.

\section{Literature Cited}

Allen, R. G.; Pereira, P. S.; Raes, R.; Smith, M. Crop evapotranspiration: Guidelines for computing crop water requirements. Rome: FAO, 1998. 300p. Irrigation and Dranaige Paper, 56

Andrade, E. M. G.; Laime, E. M. O.; Fernandes, P. D.; Lima, V. L. A.; Souto Filho, L. T.; Suassuna, J. F. Trocas gasosas da canade-açúcar sob irrigação com águas salinizadas no segundo ciclo de cultivo. In: Inovagri International Meeting, 3, 2015, Fortaleza. Anais eletrônicos... Fortaleza: INCTsal, 2015. Disponível em: <http://www.bibliotekevirtual.org/simposios/IIIINOVAGRI-2015/03.09.2015/a333.pdf>. Acesso em: Mar. 2017.

Chaves, M. M.; Flexas, J.; Pinheiro, C. Photosynthesis under drought and salt stress: Regulation mechanisms from whole plant to cell. Annals of Botany, v.103, p.551-560, 2009. https://doi.org/10.1093/ aob/mcn 125

CONAB - Companhia Nacional de Abastecimento. Acompanhamento da safra brasileira de cana-de-açúcar. Primeiro levantamento. Brasília: CONAB, 2017. 62p.

Correia, S. Potencial hídrico. Revista de Ciência Elementar, v.2, p.12, 2014. https://doi.org/10.24927/rce2014.003

Dillewijn, C. van. Botany of sugarcane. Walthham: Chronica Botânica, 1952. 433p.
Ferreira, D. F. Sisvar: A guide for its bootstrap procedures in multiple comparisons. Ciência e Agrotecnologia, v.38, p.109-112, 2014. https://doi.org/10.1590/S1413-70542014000200001

Gonçalves, E. R.; Ferreira, V. M.; Silva, J. V.; Endres, L.; Barbosa, T. P.; Duarte, W. G. Trocas gasosas e fluorescência da clorofila a em variedades de cana-de-açúcar submetidas à deficiência hídrica. Revista Brasileira de Engenharia Agrícola e Ambiental, v.14, p.378-386, 2010. https://doi.org/10.1590/S141543662010000400006

Inman-Bamber, N. G.; Bonnett, G. D.; Smith, D. M.; Thorburn, P. J. Sugarcane physiology: Integrating from cell to crop to advance sugarcane production. Field Crops Research, v.92, p.115-117, 2005. https://doi.org/10.1016/j.fcr.2005.01.011

Kumar, T.; Khan, M. R.; Abbas, Z.; Ali, G. M. Genetic improvement of sugarcane for drought and salinity stress tolerance using Arabidopsis vacuolar pyrophosphatase (AVP1) gene. Molecular Biotechnology, v.56, p.199-209, 2014. https://doi.org/10.1007/ s12033-013-9695-Z

Mortele, L. M.; Lopes, P. C.; Braccini, A. L.; Scapim, C. A. Germinação de sementes e crescimento de plântulas de cultivares de milhopipoca submetidas ao estresse hídrico e salino. Revista Brasileira de Sementes, v.28, p.169-176, 2006. https://doi.org/10.1590/ S0101-31222006000300024

Munns, R.; Tester, M. Mechanisms of salinity tolerance. Annual Review of Plant Biology, v.59, p.651-681, 2008. https://doi. org/10.1146/annurev.arplant.59.032607.092911

Reis, F. G.; Campostrini, E. Trocas gasosas e eficiência fotoquímica potencial em mamoeiro do grupo 'Formosa' cultivado em condição de campo. Bragantia, v.67, p.815-822, 2008. https://doi. org/10.1590/S0006-87052008000400002

Rhoades, J. D.; Kandiah, A.; Mashali, A. M. Uso de águas salinas para produção agrícola. Campina Grande: UFPB. 2000. 117p. Estudos da FAO, Irrigação e Drenagem, 48

Santana, M. J.; Caravalho, J. A.; Souza, K. J.; Souza, A. M. J.; Vasconcelos, C. L.; Andrade, L. A. B. Efeitos da salinidade da água de irrigação na brotação e desenvolvimento inicial da cana-deaçúcar (Saccharum spp.) em solos com diferentes níveis texturais. Ciência e Agrotecnologia, v.31, p.1470-1476, 2007. https:/doi. org/10.1590/S1413-70542007000500030

Sengar, K.; Sengar, R. S.; Singh, A. Biotechnological and genomic analysis for salinity tolerance in sugarcane. International Journal of Biotechnology and Bioengineering Research, v.4, p.407-414, 2013.

Silva, M. A.; Arantes, M. T.; Rhein, A. F. L.; Pincelli, R. P.; Santos, C. M. S.; Moura, P. C. Características morfofisiológicas e produtividade de cana-de-açúcar variam de acordo com a cultivar e o regime hídrico. Irriga, v.edição especial, p.160-177, 2015.

Smit, M. A.; Singels, A. The response of sugarcane canopy development to water stress. Field Crops Research, v.98, p.91-97, 2006. https:// doi.org/10.1016/j.fcr.2005.12.009

Souto Filho, L. T. S.; Laime, E. M. O.; Fernandes, P. D.; Suassuna, J. F.; Silva, R. C. Efeito da salinidade nas trocas gasosas de duas cultivares de cana-de-açúcar. Engenharia Ambiental, v.11, p.67$82,2014$.

Taiz, L.; Zeiger, E.; Møller, I. M.; Murphy, A. Fisiologia e desenvolvimento vegetal. 6.ed. Porto Alegre: Artmed, 2017. 858p.

Trentin, R.; Zolnier, S.; Ribeiro, A.; Steidle Neto, A. J. Transpiração e temperatura foliar da cana-de-açúcar sob diferentes valores de potencial matricial. Engenharia Agrícola, v.31, p.1085-1095, 2011. https://doi.org/10.1590/S0100-69162011000600006 